\title{
Contemporary Criteria for the Declaration of Death
}

\author{
Daniel S. Nevins
}

\section{Sheilah}

What is the precise moment of death according to halakhah?

\section{Teshuvah $^{1}$}

\section{The Process of Dying}

The time of death is perhaps the most mysterious of all human transitions. In halakhic literature, much attention has been focused on the treatment of the person up until the moment of death, and of his/her body and survivors after that point. But when, precisely, does a person die?

The prominent medical writer and surgeon Sherwin Nuland writes that "every one of death's diverse appearances is as distinctive as that singular face we each show the world during the days of life." 2 The Talmud in b. Ber. 8 a cites a beraita claiming there to be 903 forms of death. The most painful separation of soul from body is described as croup; the gentlest is death by a kiss, likened

1 I am grateful for special assistance given to me on this project by my father and teacher, Michael A. Nevins, M.D., my friend David Bar-Shain, M.D., and by my congregants, Dr. Bruce Silverman, Dr. Alex Steinbock, Dr. Richard Trosch, who are neurologists, and Dr. Leonard Rosenthal and Dr. Ronald Sherman, who are pulmonologists. The bioethics subcommittee of the CJLS helped me research and sharpen this paper. I thank its chairman, Rabbi Aaron Mackler and Rabbis Kassel Abelson, Elliot Dorff, Avram Reisner, Joel Roth and Elie Kaplan Spitz for their guidance.

This responsum was approved by the CJLS on September 8, 2004 by a vote of twelve in favor, none opposed, with one abstention (12-0-1). The current version has been revised based on continued developments in the medical literature, but the halakhic conclusions remain unchanged. In June 2018 Rabbi Leonard Sharzer, M.D. organized a conference on brain-death at the Jewish Theological Seminary with a keynote address by Dr. Alan Shewmon. His remarks, as well as mine and those of the other presenters are available in video format at: https://youtu .be/c8EgdCY6xTQ (Part 1) and https://youtu.be/dwsKık21OhE (Part 2).

2 Sherwin B. Nuland, How We Die: Reflections on Life's Final Chapter (New York: Alfred A. Knopf, 1994). 
to the withdrawal of a hair from milk. ${ }^{3}$ Some deaths are sudden, but often the final passage is a gradual transition. Contemporary medical discussions of death describe a process in which the body shuts down its vital functions until the person is declared dead. Jewish mystical sources likewise discuss a transition, three days in duration, during which the soul gradually separates from the body. ${ }^{4}$

Therefore, it may not be accurate from a physiological or a spiritual perspective to speak of a single moment of death. Some bioethicists, such as Norman Fost, question both the accuracy and the purpose of identifying a uniform standard. ${ }^{5}$ Others, like Baruch Brody, argue that it is most useful to choose different definitions of death for different courses of action. ${ }^{6}$

Nevertheless, there is an halakhic need to identify a point of transition between life and death. One set of obligations - to heal or at least to comfort the dying person-is exchanged at the time of death for a new set of obligations to prepare the body for burial, to mourn the deceased, and to comfort the bereaved. The declaration of death may be necessary for terminating treatment, especially for patients who lack relatives to authorize such a change. Defining a moment of death is also necessary to establish the date of yahrzeit. Yet it is the issue of organ donation that has lent the greatest urgency to this question. Lives can be saved by harvesting vital organs from a person who has died. But it is impossible to remove vital organs such as the heart and liver without raising the prospect of murder unless clear and defensible criteria have been established for the declaration of death.

In ordinary circumstances, breathlessness (apnea) can be verified directly, and is accompanied by other signs of death such as cardiac arrest. In the extraordinary circumstance that a ventilator-dependent patient with heartbeat has been shown to have no upper or lower brain function, and is a candidate for organ donation, precise medical and halakhic criteria of death are required. The definition of these criteria is the focus of our study. We shall argue in this paper that Judaism has historically defined life and death primarily in terms

3 For an extended study of this concept, see Michael Fishbane, The Kiss of God: Spiritual and Mystical Death in Judaism (Seattle: University of Washington Press, 1994).

4 See Rabbi Yechiel Michal Toktzinski, Gesher HaHaim 2:27 (Jerusalem, 1960).

5 Norman Fost, "The Unimportance of Death," in The Definition of Death: Contemporary Controversies, ed. Stuart J. Younger, Robert M. Arnold, and Renie Schapiro (Baltimore:Johns Hopkins University Press, 1999), 161-178.

6 Baruch A. Brody, "How Much of the Brain Must Be Dead?," in The Definition of Death, 71-82. Derick T. Wade has suggested further expanding the continuum to include patients in a "minimally conscious state." See "The Dis-integration of Death," The Lancet 36o (August 10, 2002): 425-426. 
of breathing. ${ }^{7}$ In our day, the absence of breathing is likewise the single most significant criterion in the determination of death.

\section{The Evolution of Death}

For much of Jewish and general history, the permanent cessation of breathing was the standard for determining death. By the nineteenth century (with the invention of the stethoscope), physicians began to emphasize lack of pulse rather than breathlessness in the declaration of death, though there remained difficulties in establishing either in some cases. Until the last few decades, physicians used the following methods to determine death: the observation of fixed, dilated pupils after some defined time had passed; auscultation (listening for presence of heartbeat and respiration); and eventually, rigor mortis and putrefaction. ${ }^{8}$

In the late 196os, two technological developments inspired the search for an additional method for the diagnosis of death. The first was the improvement in and profusion of ventilators which could allow a patient, while incapable of spontaneous respiration, to remain alive. Many patients used such ventilators on a temporary basis, yet it had become evident by 1968 that a significant number of people being kept alive in this fashion had no prospects of recovery. Margaret Lock described the resultant "living cadaver" as a machine-human hybrid. ${ }^{9}$

The second development was the introduction of anti-rejection medications, such as cyclosporine, which allowed far greater success in the transplantation of whole organs. By 1968, an ad hoc committee of Harvard Medical School proposed a new definition of "brain-death" to allow for the removal of ventilators in certain cases, and for the harvesting of vital organs from braindead patients for transplantation to human recipients. This process became particularly important for the harvesting of the liver and heart, which lose viability rapidly upon traditional cardio-respiratory death.

The story of the Harvard Medical School committee and the subsequent 13 years of medical and legislative activity to clarify and standardize the braindeath diagnosis is beyond the scope of our study..$^{10}$ One ambiguity that was

7 [2018 update: In the original paper I used the words respiration and breathing interchangeably, but they are not identical. Respiration refers also to the exchange of gases on the cellular level and continues even when a person is incapable of breathing.]

8 I thank my father, Michael A. Nevins, M.D., for this description.

9 Margaret Lock, Twice Dead: Organ Transplants and the Reinvention of Death (Berkeley:University of California Press, 2002), 40.

10 See Martin S. Pernick, "Brain Death in a Cultural Context: The Reconstruction of Death, 
quickly clarified was the equation of brain-death with what came to be called "whole brain-death," defined by the destruction of the cerebrum and the brain stem, rather than "higher brain-death" which describes the destruction of the cerebrum and results in the permanent loss of consciousness.

Today, "brain-death" refers to the complete loss of function of all areas of the brain. Still, the term "brain-death" remains confusing, since the issue is human death defined by neurological criteria. This term is also often misapplied in common parlance to refer to prolonged and apparently permanent cases of coma. For example, family members sometimes refer to a comatose patient as "brain-dead" even though they are breathing spontaneously.

Legally, brain-death is defined as "the irreversible cessation of all functions of the entire brain, including the brain stem."11 Patients in a persistent vegetative state may have lost higher brain functions, but they still respond to certain stimuli, may breathe without ventilators, and are not considered by rabbinical or medical authorities to be dead.

The notion of brain-death was first proposed in 1968 and gained currency and legal status starting in the 1970s. Nonetheless, the definition of death has grown more complicated and controversial. ${ }^{12}$ In recent years, the medical literature has produced numerous critical evaluations of the brain-death diagnosis. $^{13}$

There are recent detailed protocols available for the diagnosis of braindeath, ${ }^{14}$ yet such careful methods may not be consistently employed by physicians before calling in the transplant team. Protocols may vary from the emergency room to the critical care units, from hospital to hospital, and from doctor to doctor. ${ }^{15}$ Neurosurgeons Michael Wang and J. Peter Gruen and nurse Pamela

1967-1981," in The Definition of Death, 31-33; and the chapters, "Locating the Moment of Death," and "Making the New Death Uniform," in Lock, Twice Dead, 78-126.

11 American Medical Association and American Bar Association, 1983.

12 For a harsh critique, see Gary Greenberg, "As Good As Dead: Is There Really Such a Thing As Brain Death?," New Yorker, August 13, 2001, 36-41.

13 For example, see Ronald Cranford, "Even the Dead Are Not Terminally Ill Anymore," Neurology $5_{1}$ (1998): 1515-1516; D. Alan Shewmon, “Chronic 'Brain Death,” Neurology $5^{1}$ (1998): 1538-1545; The Hastings Center Report of July-August 2001; and James Bernat, "Refinements in the Definition and Criteria for Death," in The Definition of Death. See also the editorial by Michael Swash and Richard Beresford, "Brain Death: Still-Unresolved Issues Worldwide," Neurology 58 (2002): 9-10. [2018 Update: Neurologist D. Alan Shewmon has continued to raise fundamental questions about the validity of the brain-death diagnosis. His concerns will be addressed below.]

14 See Eelco F.M. Wijdicks, "The Diagnosis of Brain Death," The New England Journal of Medicine 344, no. 16 (April 19, 2001): 1215-1221.

Based on personal conversations with emergency, pulmonology and neurology special- 
Wallace documented the variety of tests used in the diagnosis of brain-death in one California hospital, and called for greater uniformity in how this diagnosis is made. ${ }^{16}$ They concluded that "physicians are trusted to rigorously apply accepted standards and practices when making the diagnosis of brain-death. Failure to strictly adhere to the whole-brain guidelines jeopardizes the public's trust in the clinical diagnosis of brain-death."

Bioethicists initially raised concerns that the new definition of death was driven simply by the desire for donated organs, and some physicians pointed to the continuation of minimal brain function even in cases of "whole braindeath. ${ }^{17}$ Nonetheless, Western societies quickly adapted to the new standard.

Yet in Japan, a society with comparable levels of education and medical resources, the new standard of death has not been accepted so readily. Despite concern for saving the lives of potential organ recipients, Japanese society has been slow to view the patient who appears alive — if not lively — to be a "living cadaver." As a result, donor cards in Japan ask people to select either a traditional cardio-pulmonary definition of death or brain-death before authorizing removal of their organs. ${ }^{18}$

Even in America, where the acceptance of brain-death is presumed to be widespread, physicians are wary of the presence of relatives during the administration of clinical tests for brain-death. ${ }^{19}$ Brain-dead patients may continue to exhibit spinal reflexes including the "Lazarus sign" in which the body briefly sits up and raises its arms when the ventilator is shut off, making it appear as if the patient had been more "living" than "cadaver."

ists. Transplant teams follow separate protocols for determining death before harvesting vital organs.

16 Michael Y. Wang, Pamela Wallace, and J. Peter Gruen, "Brain Death Documentation: Analysis and Issues," Neurosurgery, September 2002, 731-736. A similar claim is made by Sam D. Shemie, Christopher Doig, and Philip Belitsky, "Advancing toward a Modern Death: The Path from Severe Brain Injury to Neurological Determination of Death," Journal of the Canadian Medical Association 168, no. 8 (April 15, 2003): 993-995.

17 Specifically, "the continued hypothalamic secretion of antidiuretic hormone (ADH) sufficient to prevent diabetes insipidus" in patients declared brain dead according to accepted protocol. James Bernat, in The Definition of Death, 86. However, Bernat argues that ADH secretion should not be classified as a "clinical function" of the brain, and therefore is not an impediment to the diagnosis of brain-death.

18 See Twice Dead; and also Masahiro Morioka, "Reconsidering Brain Death: A Lesson from Japan's Fifteen Years of Experience," in The Hastings Center Report, July-August 2001. Also see R.D. Truog, "Is It Time to Abandon Brain Death?," The Hastings Center Report 27, no. 1 (1997): 29-37.

19 See "Really, Most Sincerely Dead: Policy and Procedure in the Diagnosis of Death by Neurologic Criteria - Views and Reviews," Neurology 62 (May 25, 2004): 1683-1686.

See Fred Plum, "Clinical Standards and Technological Confirmatory Tests in Diagnosing 
Nevertheless, a broad American consensus in support of accepting braindeath as a new standard has taken hold in the past three decades, driven no doubt by the prospect of saving lives through the harvesting of vital organs from people who "no longer need them" and avoiding futile treatment. The standard definition of death has been clarified by the Uniform Declaration of Death Act (1981), which "has been upheld by statute or judicial opinion in each of the 50 states and has been at least partially adopted in most of the world's industrialized nations":21

An individual who has sustained either (1) irreversible cessation of circulatory and respiratory functions, or (2) irreversible cessation of all functions of the entire brain, including the brain stem, is dead. ${ }^{22}$

Differences remain between states in the required form of diagnosis; New Jersey and New York are distinct for granting a religious exemption from the diagnosis of brain-death. ${ }^{23}$ In a comprehensive survey of brain-death legislation across the world, Wijdicks found that 70 of 80 countries surveyed had guidelines or codes of practice governing the declaration of brain-death, although the standards for diagnosis varied widely. ${ }^{24}$ The variety of diagnostic procedures among medical professionals lends greater urgency for clarity among practitioners of halakhah. Our purpose in this responsum is to review the current medical standards of brain-death diagnosis and to determine whether these can satisfy the requirements of Jewish law.

[2018 update: The case of Jahi McMath has attracted significant attention. ${ }^{25}$ She was diagnosed as brain-dead in 2013, but maintained ventilator-dependent heartbeat until 2018, during which time she experienced puberty and was able to survive outside of the hospital. Video files documented her family's claims that Jahi responded to verbal commands with limb movement. Dr. Alan Shewmon examined her and confirmed these claims. He questions her brain-death diagnosis,

Brain Death," in The Definition of Death, 53. Such a case was described in The New York Times, October 8, 2002.

21 Plum, "Clinical Standards," 39.

22 A more technically-precise statement which addressed the issue of confounding factors was published in JAMA 246 (1981): 2184-2186.

23 New Jersey provides the exemption in the original statute, New York in a separate regulation.

24 Eelco F.M. Wijdicks, "Brain Death Worldwide: Accepted Fact but No Global Consensus in Diagnostic Criteria," Neurology 58 (January 2, 2002): 20-25.

25 See Rachel Aviv, "What Does it Mean to Die?" New Yorker, February 5, 2018, https://www .newyorker.com/magazine/2018/o2/o5/what-does-it-mean-to-die. 
arguing that she was instead in a minimally conscious state. His explanation is that she had a different condition of global ischemic penumbra (GIP), which mimics brain-death. ${ }^{26}$ Shewmon argues that the only way to verify brain-death, rather than GIP, would be to prove that there is absolutely zero blood flow to any part of the brain, which is not currently possible. He further argues that the apnea test may be a self-fulfilling prophecy, in some cases causing the condition of braindeath that it proposes to measure. His position would hold all declarations of brain-death in abeyance, preventing the donation of vital organs on this basis. Shewmon prefers using the non-heart-beating protocol for organ donation. This position has its own critics, since cardiac arrest in such cases may not be irreversible. We acknowledge Shewmon's concerns, but also that his position is an outlier in the neurological and bioethics discourse. ${ }^{27}$ See update to final conclusions below.]

Within the halakhic community, the acceptance of brain-death remains unsettled. ${ }^{28}$ As we shall see, Conservative rabbis have generally accepted the idea of whole brain-death, while Orthodox rabbis are divided on the subject. Yet many of the articles from the 1970s and 1980s employed now-obsolete criteria such as a flat electro-encephalogram (EEG); this is now considered an unreliable indicator of brain-death. ${ }^{29}$

The development of neurological criteria for the declaration of death has challenged halakhic authorities either to adopt or to reject the new standards. While much has been written on both sides of the issue, the crucial question of what specific diagnostic criteria are required for an halakhic declaration of death has received relatively little attention. Although diagnostic procedures may be constantly evolving, it is incumbent upon the local poseq to become familiar with contemporary criteria of death to guide families faced with difficult deci-

26 D. Alan Shewmon, "Truly Reconciling the Case of Jahi McMath," Neurocritical Care, August 15, 2018.

27 Ariane Lewis, "Reconciling the Case of Jahi McMath," Neurocritical Care, June 19, 2018.

28 See Zev Farber, ed., Halakhic Realities: Collected Essays on Brain Death (Jerusalem: Maggid Books, 2015), for a sample of Modern Orthodox studies.

29 James L. Bernat, writes that EEG activity persists in some patients "unequivocally determined to be brain dead by accepted tests. This rudimentary EEG activity neither responds to sensory stimuli nor appears to represent coherent brain functioning. Rather, it represents isolated nests of neurons whose random and purposeless cellular electrical activity can be recorded technologically but whose functioning is utterly divorced from that of the organism as a whole." See "Refinements in the Definition and Criteria for Death," in The Definition of Death, 87. See Fred Plum, in the same volume, 42-43. False negatives are also possible with EEG. EEG is increasingly being supplanted by transcranial Doppler ultrasonography as a confirmatory test of brain-death (see below). 
sions at the end of life. This paper aims to apply classical rabbinic sources to contemporary medical norms in order to establish a working halakhic definition of death for our time.

\section{The Definition of Death in Classical Rabbinic Texts}

\section{Respiratory Death}

The primary rabbinic text to define physical criteria of death is from Talmud Tractate Yoma. The relevant Mishnah, m. Yoma 8:7 (found in the Babylonian Talmud on 83a), states:

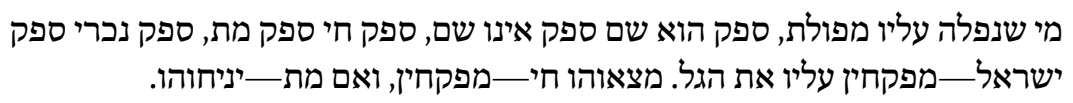

If a building collapsed [on Shabbat], and it is unknown if a person is [trapped] there or not, whether he is alive or dead, gentile or Jew, they should clear the rubble off him. If they find him alive, they should extricate him; if he is already dead, they should leave him [until after Shabbat $].^{30}$

The Gemara, b. Yoma 85a, seeks to clarify how the rescuers are to determine whether the victim is dead or alive:

$$
\text { תנו רבנן: עד היכן הוא בודק? עד חוטמו, ויש אומרים: עד לבו. }
$$

The Rabbis taught: How far [into the rubble] should they check [to determine if he is alive]? Until his nose. Some say: until his heart.

Rashi explains that this question applies when the victim is found absolutely still—like a corpse:

עד היכן הוא בודק-אם דומה למת שאינו מזיז איבריו, עד היכן הוא מפקח לדעת האמת?

"How far should they check?" If he appears dead, for he is not moving his limbs, how far should they excavate to learn the truth?

30 All translations are my own unless otherwise noted. 
In such a case, which criteria are necessary to verify that the victim is deadcardiac or respiratory? ${ }^{31}$ Although it might be expected that clearing rubble off the chest would allow the victim to breathe, the halakhah assumes that respiration can be checked even if only the head is exposed. What, then, is the dispute about? After a short digression in the Gemara, Rav Papa explains that this dispute relates only to a case in which the victim is uncovered feet (and thus chest) first — some would accept evidence of asystole [cardiac standstill] as conclusive; others would insist on digging further until the head is uncovered to confirm the lack of breathing:

\section{אמר רב פפא: מחלוקת ממטה למעלה, אבל ממעלה למטה, כיון דבדק ליה עד חוטמו-

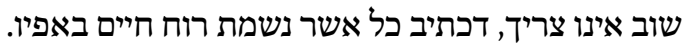

Rav Papa says, the dispute is from the bottom [of the victim's body] upward; but if [he were found] top to bottom, once his nose had been checked [for signs of breathing], nothing further is required, for it is written, "all in whose nose is the breath of life" (Gen 7:22).

Therefore, the primary criterion of death is respiratory, although some would accept cardiac criteria as conclusive in cases where the person could not be checked for breathing. This latter view is rejected by the codes of halakhah.

Rashi explains Rav Papa's analysis with diagnostic precision:

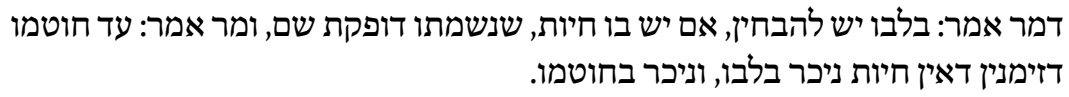

One opinion is to inspect the heart-if it is alive- that his spirit is beating there; the other opinion is to continue to the nose, for at times life is not discernible at the heart, but it is discernible at the nose.

Rashi's gloss indicates that cardiac arrest is harder to discern than is the absence of breathing. Yet from the Gemara it is evident that breathlessness is not merely easier to verify than cardiac standstill; it also accords with the Biblical concept of the "breath of life." In other words, the Gemara indicates that respiratory failure bears more significance than does asystole.

31 y. Yoma 8:5 (45b) provides an interesting variant. In this version, the dispute concerns the best method of proving respiratory failure - at the nose or at the diaphragm. Cardiac criteria play no role at all. It is possible that even the Bavli's reference to checking "to his heart" refers to the rising and falling of the chest. 
The Gemara's breath-based standard of death is codified in the medieval codes of Jewish law. Maimonides states that the absence of respiration discernible at the nose is sufficient evidence of death: ${ }^{32}$

בדקו עד חטמו ולא מצאו בו נשמה מניחין אותו שם שכבר מת.

If they examined his nostrils and found no breath there, they leave him there, for he is already dead.

Rabbi Karo makes the same ruling in the Shulhan Arukh:

אפי' מצאוהו מרוצץ, שאינו יכול לחיות אלא לפי שעה, מפקחין ובודקים עד חוטמו; אם לא הרגישו בחוטמו חיות, אז ודאי מת לא שנא פגעו בראשו תחלה לא שנא פגעו מבו ברגליו

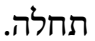

Even if a person were discovered crushed, who cannot live for more than a moment, they should continue excavating and checking him until his nostrils; if they detect no life [i.e. breathing] at his nostrils, then he is certainly dead, and it matters not whether they first found his head or his legs. ${ }^{33}$

The Mishnah Berurah explains the final phrase to mean that absence of heartbeat alone does not prove death, but absence of breathing alone is conclusive. ${ }^{34}$ The Babylonian Talmud and codes of Jewish law view lack of breathing, not cardiac arrest, as the primary criterion for the declaration of death. ${ }^{35}$

Although the Rabbis considered absence of breathing to be sufficient evidence of death, it is evident that they meant permanent apnea. Maimonides warns to wait for some time to verify permanent cessation of respiration in case the person had merely fainted. ${ }^{36}$ Of course, people who faint continue to breathe, but it could be difficult to detect their respiration. Rambam's ruling is confirmed by Rabbi Karo in Beit Yosef.${ }^{37}$ Rabbi Isserles makes a similar statement regarding a woman in labor who has apparently died—a caesarean

\footnotetext{
32 Mishneh Torah, Hilkhot Shabbat 2:19.

33 Shulhan Arukh, он 329:4.

34 Mishnah Berurah 329:11.

35 In section v, we shall scrutinize Rabbi J. David Bleich's surprising argument that Rashi establishes the primacy of a cardiac standard.

36 Mishneh Torah, Hilkhot Eivel 4:5.

37 Beit Yosef, YD 339:1. The Talmudic basis is found on Šabb. 151b.
} 
section should not be attempted lest she is merely comatose and now would be killed by the surgery. ${ }^{38}$

Such fears of premature declarations of death became greatly pronounced in both general and Jewish society in the late eighteenth and nineteenth centuries. In Germany, the fear of apparent death (Scheintod) leading to live burial became a sensation, prompting civil legislation in 1772 to mandate a three-day waiting period before burial. This law impinged upon the Jewish custom of burying, when possible, within a day of death. The Jewish community, led by Rabbi Jacob Emden and philosopher Moses Mendelssohn, successfully secured a Jewish exemption from this law. Yet many Jews, agitated by radical maskilim who dismissed rabbinic authority, were shaken in their confidence to diagnose death and proceed with burial within 24 hours. ${ }^{39}$ Permanent lack of pulse and breath can be hard to verify, particularly in cases involving hypothermia and drowning.

In our day, the extraordinary adjustment being proposed is to view a patient who is apparently breathing (albeit via a ventilator) and maintaining a heartbeat as nevertheless dead. To be blunt, this means removing functioning vital organs from one person and giving them to another. Based on the texts reviewed above, such an adjustment would seem unthinkable. Indeed, one might expect a horrified reaction in our day similar to the Scheintod panic of earlier generations. Surprisingly, this has not been the case in Western societies, and it has also not typified the responses of many halakhic authorities. The measured Jewish response may be motivated by the prospect of saving lives, but it is also grounded in classical halakhic examples of an additional set of texts used for the diagnosis of death.

\section{Alternative Evidence of Death: Fatal Neck and Back Injuries}

So far, we have been dealing with the diagnosis of death in a person whose body appears completely inert and lifeless. The Rabbis also discussed cases in which death could be declared, despite continued convulsions of the body, based on the observation of mortal injury. Although the respiratory criteria dis-

38 Rema to он 330:5. See Magen Avraham there, n. 11.

39 See John M. Efron, Medicine and the German Jews: A History (New Haven: Yale University Press, 2001), 95-104. Margaret Lock also discusses the eighteenth-century panic over premature burial in Twice Dead, 66-69. This uncertainty among Jews over proving a diagnosis of death was still a source of concern to Hatam Sofer (YD 338). Some contemporary Jews even recalled a beraita from Tractate Semahot (8:1) of a Jewish Rip Van Winkle, who was found alive twenty-five years after burial in a crypt — and who went on to marry and have children! Yet Rabbi Emden and then Hatam Sofer railed against viewing this story as a precedent. 
cussed above have been the primary means for determining death in Jewish texts, there is an alternative criterion for death even in the classical literature: destruction or severance of the spinal cord. The Biblical story of the death by neck injury of the priest Eli after the Holy Ark had been captured in battle by the Philistines (1Sam 4:18) is studied by the Rabbis in b. Hul. 21 a to understand the significance of fatal neck injuries:

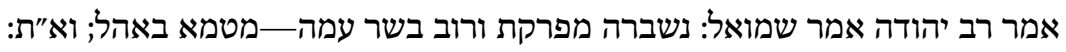

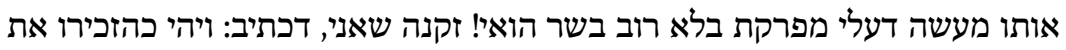

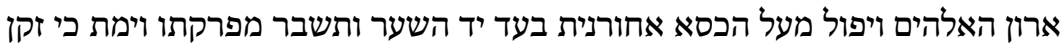

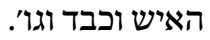

Rav Yehudah said in the name of Shmuel: if a person's spine was broken and most of the surrounding neck severed, he defiles in a tent [i.e. he is considered dead and conveys ritual impurity]. But you may object - what about the case of Eli, whose spine was broken, but not most of his neck [and yet he was considered dead]? The elderly are different, for it is written, "When he [the messenger] mentioned [the capture of] God's ark, he [Eli] fell backwards off his chair by the side of the gate, breaking his spine, and he died, for he was an old man and also heavy."

According to Rav Yehudah, citing Shmuel, the observation that a person's neck is broken and mostly severed is by itself sufficient evidence of death. Yet because Eli was elderly, he was considered dead even without his neck being severed. ${ }^{40}$ That is, injuries do not occur in isolation from other causes of frailty or illness in a person.

The Hullin text continues to describe other types of spinal cord injuries that would leave a person legally dead, even should his body continue to convulse:

אמר ר'שמואל בר נחמני א"ר יוחנן: קרעו כדג-מטמא באהל. א"ר שמואל בר יצחק:

Rav Shmuel bar Nahmani said in the name of Rabbi Yoḥanan, if he were torn like a fish, he defiles in a tent. Said Rav bar Yitzhak, provided his back [were sundered].

40 In his commentary to the Rosh, Ma'adanei Yom Tov, Rabbi Lipman HaLevi Heller makes a fine distinction between the description of Eli as heavy, which he believes caused the fall, and elderly, which caused him to die even without his neck being gashed. Folio 149a in the Vilna Shas. 
Rashi explains that such a mortally wounded person "defiles in a tent" even if his body continues to convulse. The Shulhan Arukh ${ }^{41}$ restates this Gemara, claiming that some people are so grievously wounded as to be considered dead even while displaying signs of life:

\section{מי שנשברה מפרקתו א ורוב בשר עמה, וכן מי שנקרע ב מגבו כדג, אפילו עדיין הוא חי, חשיב כמת, ומטמא.}

Someone whose spine is broken, and most of whose neck is severed, or one whose backbone is ripped out like a fish, even if he is still alive [i.e. moving], is considered as if dead, and renders [others present] ritually impure.

In addition to these sources that which detail spinal injuries, there are several rabbinic sources that equate the decapitation of animals with death, despite persistent signs of life. The most often cited source is m. 'Ohal. 1:6:

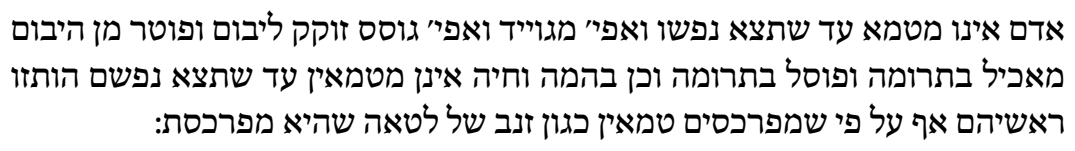

A person does not render others impure [i.e. die] until his soul departs. Even if he is severely lacerated or nearly dead, he is still considered alive to fulfill or seek exemption from leviratic marriage, to entitle [his mother or wife] to eat priestly tithes or to deprive her. So too cattle and beasts do not render unclean until their life departs. If their heads are severed, even if their bodies continue to convulse, they are already impure, just like the severed tail of a newt twitches [even after it has been cut off].

Maimonides explains פרכוס, the convulsions of a decapitated animal, saying:

והתנועה שמתנועעין האברים אחר המות קוראים אותה פרכוס.

The movement of the limbs after death is called "pirkus."42

41 YD 370.

42 Peirush Mishnayot, Yosef Kapach translation, Mosad HaRav Kook (5727), 3:15o. 
In Hilkhot Tum'at Meit, he codifies the distinction evident in the Mishnah between a terminally ill person, who is considered alive, and a mortally wounded person, who is considered dead despite the continued convulsions. ${ }^{43}$

In b. Git. 7ob Rav Yehudah in the name of Shmuel describes the case of שחט בו שנים או רוב שנים, a man whose esophagus and trachea have been severed, but who is nevertheless allowed to execute a bill of divorce for his wife. Jewish law requires the husband to be not only alive but lucid while the get is written, witnessed, and then delivered to his wife! If he can't breathe, why isn't he considered to be legally dead?

Perhaps some air could still get to the man's lungs through the severed windpipe, or maybe he was simply holding his final breath, and he had a very speedy scribe at his side. Surely a person with a severed trachea and esophagus could not remain conscious for more than a few brief moments. Later in the Gemara this case is challenged, since Rav Yehudah also said in the name of Shmuel that a man who had his trachea and esophagus slit and ran away-observers can testify that he has died. Indeed, Rambam cites this as halakhah in Hilkhot Gerushin 13:17. This may not mean that he was considered dead at the moment that he was last seen running, but his death is deemed by halakhah to be inevitable and imminent due to his inability to breathe.

These strange cases are comparable to an animal that has been ritually slaughtered-its trachea and esophagus are severed but it may retain consciousness for a few moments. Nevertheless, the animal's imminent death is considered inexorable. ${ }^{44}$ It is noteworthy that שחיטה does not involve severing the carotid artery. Rabbi Yehudah does differ from this position (b. Hul. 27a), requiring severing the וורידין, but the Gemara on $28 \mathrm{~b}$ clarifies that Rabbi Yehudah's opinion applies only to birds that will be roasted whole, and that his purpose is to expel the blood, not to qualify the slit of the artery as an integral part of שחיטה.45 As Rashi says there, "life does not depend on the blood vessels, and they needn't be mentioned except in regard to [expelling] the blood."46

רמב"ם הלכות טומאת מת פרק א. המת אינו מטמא עד שתצא נפשו אפילו מגוייד או גוסס, אפילו

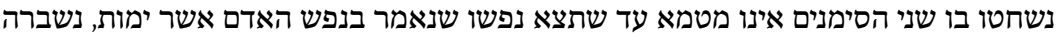

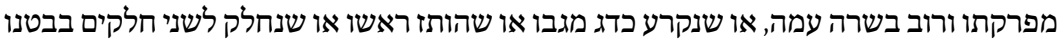
הרי זה מטמא אף על פי שעדיין הוא מרפרף ערוג באחד מאיבריו. Because of the laws of shehitah, a Jew may eat the meat while it still quivers, but a nonJew is forbidden the flesh based upon אבר מן החי. See b. Hul. 121b, and Tanḥuma (Buber, 180) VaYeishev 6.

45 The Tur confirms this at YD 22:1.

רש"י מסכת חולין דף כח עמוד ב. מאחר שלא הוזכרו וורידין-_כלומר אין חיות תלויה בהן ואין 46 צריך להזכירו אלא משום דם כח למה אתוד מאה מצריכו שחיטה. 
This confirms that halakhah employs respiratory, not circulatory, criteria in the determination of death.

Another text that clarifies the legal consequences of decapitation comes from the laws of Shabbat. A significant halakhic concept is that if an action is generally permitted on Shabbat, but it has a forbidden and unavoidable consequence, then the first action is not allowed. This theory is known by the expression, פסיק רישיה ולא ימות "If you cut off [a chicken's] head, will it not die?"47 In other words, decapitation leads inexorably to death, even if temporary signs of bodily life persist. The heart may be beating, and the limbs may be moving, but the chicken cannot breathe, and it therefore is considered dead.

\section{Synthesis of the Classical Halakhic Sources}

Despite the ambiguities that result from the Talmud's diverse descriptions of death, an underlying principle may be deduced. The key to the halakhic understanding of death comes from the words עד שתצא נפשו, "until his life departs." ויפח באפיו נשמת: נפש is explicitly connected to breath by the Torah word " חיים ויהי האדם לנפש חיה the man became a living creature" (Gen 2:7). Other words that describe the animating spirit that defines life, רוח and and likewise relate to respiration.

The מגוסס mentioned in our Mishnah are nearly dead, but they are still breathing, and are therefore considered alive. One who is decapitated, or whose trachea is slit is no longer able to breathe and is therefore considered dead within moments of the injury. The Yoma text describes a motionless person who is declared dead based on respiratory failure. The Hullin and Ohalot texts describe humans (and animals) who, though still moving, are declared dead due to catastrophic injury to the neck or chest. Such injuries prevent the victim from breathing. Movement of the body implies continued cardiac activity. But the victim's inability to breathe means that death is imminent. Indeed, Rambam's definition of פרכוס captures this state precisely—the movements made after death.

Similarly, the Gittin text allows that a person may remain alive for a few moments after his trachea is slit, but it still considers him to be dead with no further inspection after that. Severe neck and torso injuries make breathing impossible and death inevitable. The case of Eli, whose neck was broken but not severed, and yet who was considered dead without verifying lack of breathing, is presented as an exception to the general practice.

47 See, for example, b. Šabb. 103a, and many similar sources. We may even discern in the future tense of "he will die" that decapitation leads to death rather than constitutes death. 
At the other end of life, the heart of a human embryo begins to pump fluid through blood vessels on day twenty of gestation. ${ }^{48}$ Nevertheless, it is not deemed a נפש, a true life, until many months later, עד שתצא לאויר העולם "when it exits [the womb] into the air of the world."49 The fetus has a special status as part of the mother's body, but it is not considered an independent life until it is born and begins to breathe.

Thus, it is not movement or even pulse which ultimately defines life and death, but the ability to breathe. This interpretation harmonizes the Talmudic and later halakhic materials, yielding a consistent standard for the start and end of life.

While some have argued that the decapitation texts constitute an alternative to the breathlessness standard, there is no reason to assume that the ancient Rabbis or their gentile contemporaries ascribed particular significance to the functioning of the nervous system in determining death. The spinal cord is ignored in שחיטה, and all of the neck-injury cases except for that of Eli require that the neck be mostly severed in order for death to be declared without testing directly for breathing. Our synthesis of the disparate rabbinic sources integrates the legal and linguistic data into a coherent halakhic approach which will guide us as we explore the medical literature.

\section{Current Medical Criteria for the Diagnosis of Death ${ }^{50}$}

In The New England Journal of Medicine, Dr. Eelco F.M. Wijdicks provides a protocol detailing a neurological examination used to declare brain-death. ${ }^{51}$ The first priority is to assess whether the patient's condition is permanent, or is rather the temporary result of reversible factors. Before an examination for brain-death can proceed,

48 The Merck Manual of Medical Information, Second Home Edition (Whitehouse Station, NJ: Merck \& Co., 2003), 1437.

49 Rashi on b. Sanh. 72b, s.v. yatza rosho. See Rabbi Susan Grossman, "Partial Birth Abortion and the Question of When 'Life' Begins," 6. This responsum was approved by the CJLS, September 17, 2003. A different conclusion about the precise moment of birth was defined by Rabbi Avram Reisner in his responsum, "Ein dohin nefesh mipnei nefesh," approved by the CJLS on December 19, 2001.

50 For an excellent online resource, see www.braindeath.org/clinical.htm. See also the book, Brain Death, ed. Eelco F.M. Wijdicks (Philadelphia: Lippincott Williams \& Wilkins, 2001), esp. ch. 4 .

$5^{1} \quad$ NEJM 344, no. 16 (April 19, 2001): 1215-1221. See n. 14 above, and his book, Brain Death (2001). 
the following prerequisites [must be] met: the ruling out of complicated medical conditions that may confound the clinical assessment, particularly severe electrolyte, acid-base, or endocrine disturbances; the absence of severe hypothermia, defined as a core temperature of $32^{\circ} \mathrm{C}$ or lower; hypotension; and the absence of evidence of drug intoxication, poisoning, or neuromuscular blocking agents.

Once these confounding factors have been ruled out, the clinical exam for brain-death commences. Wijdicks describes in great detail a three-part clinical exam, which tests for the lack of spontaneous or responsive cranial nerve activity, the absence of brain-stem reflexes, and apnea. The latter is tested by turning off the ventilator for several minutes and measuring the rise of $\mathrm{CO}_{2}$ in the bloodstream. These tests are typically repeated between six and 24 hours after the first exam. ${ }^{52}$ Dr. Plum's detailed protocol is presented below as an appendix.

The brain-death protocol for pediatric cases differs from the standards described for adults. ${ }^{53}$ Because most pediatric cases of brain-death are caused by severe asphyxial injury (which may injure organ systems other than the brain), organ procurement from pediatric donors is rare.

The apnea test-which measures the presence or absence of effective breathing - is typically the final and conclusive clinical examination for braindeath. Dr. Plum writes,

The apneic test represents the ultimate physiological-clinical test to diagnose brain-death. I know of no personal observation of a responsibly conducted, positive apnea test that has been reversed by subsequent recovery. Conversely, instances of omission of the apnea test have led to potentially unfortunate errors or premature assumptions of brain-death. ${ }^{54}$

52 Andrew Newberg, Abass Alavi, Salina van Rhijn, Adolfo Cotter, and Patrick Reilly, "Radiologic Diagnosis of Brain Death," in JAMA 288, no. 17 (Nov. 6, 2002): 2121. The six-hour wait is cited from the Quality Standards Subcommittee of the American Academy of Neurology, published in Neurology 45 (1995): 1012-1014. In Michigan, the standard waiting period is 24 hours, according to a personal communication with Dr. Bruce Silverman.

53 See Stephen Ashwal, "Clinical Diagnosis and Confirmatory Testing of Brain Death in Children," in Brain Death, ch. 5. He writes, "the neurologic examination is more difficult to perform and interpret because of the smaller size of the patient, immaturity of certain development reflexes being tested, and pathopshysiologic differences due to the presence of open sutures and fontanels in the neonate and infant."

54 "Clinical Standards and Technological Confirmatory Standards in Diagnosing Brain Death," in Younger, The Definition of Death, 40. 
Thus, after confounding factors have been ruled out and the patient has demonstrated neither any response to painful stimuli to the higher brain nor to the examination of brain-stem reflexes, the apnea test confirms the braindeath diagnosis.

Although the patient might move during the test, the absence of any breathing efforts, confirmed by a rise of carbon dioxide levels in the blood, shows that the patient is not breathing spontaneously. This test is repeated and, if it confirms the total lack of respiration, death is declared. Bodily movements during the exam are understood as spinal cord and not brain stem reflexes. These spinal cord reflexes are consistent with the rabbinic literature's description of פרכוס, spasmodic motion after death.

In rare $\operatorname{cases}^{55}$ when the apnea test cannot be administered due to confounding factors (such as the presence of barbiturates that cannot be cleared or initial $\mathrm{CO}_{2}$ levels that are too high or too low) radionuclide brain perfusion and other imaging techniques are used to verify a diagnosis of brain-death. Such diagnosis depends upon measurement of "the complete absence of [blood] flow throughout the brain and the internal carotid arteries." ${ }^{n 6}$ This exam is seldom used since it is much more complicated and is not as conclusive as the protocol described above.

A simpler option is transcranial doppler ultrasonography (TCD), "a noninvasive monitoring tool which allows imaging of blood flow velocities in intracranial blood vessels." 57 Such tests may play an important ancillary role in the diagnosis of brain-death, but they do not alone suffice for medical purposes. In a study of cerebral blood flow after brain-death, doctors W. Mel Flowers and Bharti R. Patel conclude that "visualization of arterial flow does not exclude brain-death, but the diagnosis should be confirmed by repeat studies and other means." ${ }^{58}$ Wijdicks cautions that, "absent flow intracranially may be due to transmission difficulties and in itself is not a criterion for death."59

If there is no blood flow in the brain, does this not prove the patient's inability to breathe, albeit less directly than the apnea test? In fact, intracranial blood

55 Neurologist Bruce Silverman, M.D., who regularly examines patients for brain-death, has not ordered the radionuclide test once in the past 15 years. Personal communication.

56 See n. 53, "Radiologic Diagnosis of Brain Death."

57 V. Singh, J.P. McCartney, and J.C. Hemphill, III, "Transcranial Doppler Ultrasonography in the Neurologic Intensive Care Unit," Neurology (India) (June 2001), Suppl. 1:S81-89.

58 W. Mel Flowers, Jr., and Bharti R. Patel, "Persistence of Cerebral Blood Flow After Brain Death," Southern Medical Journal 93, no. 4 (April 2000): 364-370; and in an earlier article, "Accuracy of Clinical Evaluation in the Determination of Brain Death," in Southern Medical Journal 93, no. 2 (February 2000): 203-206. 
flow exams measure the carotid arteries, but the medulla, which directly controls the respiratory impulse, is supplied by the vertebral artery. ${ }^{60}$ Thus it is possible that a patient could show no intracranial blood flow, but still be capable of spontaneous respiration.

From the perspective of halakhah, neither radionuclide brain perfusion imaging nor TCD measures respiration, and therefore these tests do not suffice to prove death. In contrast, the clinical neurological examination culminating in the apnea test has been proven effective over time as a verification of the complete absence of respiration and of brain-death. Should a future test of total respiratory failure be developed, it would apparently satisfy the halakhic definition of death. Meanwhile, apnea is the best halakhic measurement of death in a ventilator-dependent patient who has met all the other criteria of braindeath.

[2018 update. This remains the medical consensus, but we note the objections raised by Alan Shewmon. ${ }^{61}$ He argues that the apnea test can demonstrate only the loss of brain function, not necrosis of the brain, and thus it does not prove death. Moreover, by cutting off the supply of oxygen to the brain during the apnea test, clinicians may cause cellular necrosis. These suggestions are alarming. Yet the halakhic texts are concerned not with cellular life, but with organic function. As we have shown, if a person is injured in a way that makes it impossible for them to breathe, that is evidence of death. We would add that if a person is incapable of spontaneous breathing, but does possess other evidence of brain function, perhaps their apnea could be caused not by brain-death but rather by an upper spinal cord injury or global ischemic penumbra. If so, evidence of even minimal consciousness could be declared "hayut" (vitality) and prevent an halakhic declaration of death, halting removal of vital organs.]

\section{Halakhic Responses to Brain-Death Criteria}

Soon after the discussion of brain-death standards entered American legal discourse, halakhic authorities here and then in Israel began to review traditional texts such as those mentioned in Section II to determine the Jewish status of brain-death. Dozens of articles have been published to date, and it will not be

6o Neurologist Richard Trosch, M.D., personal communication.

61 See D. Alan Shewmon, "False-Positive Diagnosis of Brain Death Following the Pediatric Guidelines: Case Report and Discussion," Journal of Child Neurology 32, no. 14 (2017):11041117 . 
possible to review them here. We will rather focus on specific rationales and guidelines offered by the defenders and critics of using brain-death criteria to declare death.

Although פקוח נפש, saving a life, is one of the highest of all Jewish values, avoiding homicide supersedes even this commandment. As the Rabbis said, דוחין נפש מפני נפש, "one life cannot be disposed of in favor of another."62 Nevertheless, halakhic authorities have been willing to examine new criteria of death to see if additional lives might be saved either by transplantation of vital organs, or by making scarce medical resources available to other patients. Concerns for not desecrating the body (ניוול המת), not delaying burial (הלנת המת), not profiting from the dead (אין הנאה מן המת) and maintaining the general dignity of the dead (כבוד המת) remain operative, but do not outweigh the requirement to save a life (פקוח נפשת). The first task, of course, is to determine if the potential donor is truly dead.

In 1976, the journal Conservative Judaism published articles by Rabbi Daniel C. Goldfarb and Rabbi Seymour Siegel z"l, each of whom reviewed the relevant rabbinic sources and contemporary medical informationand found grounds for "updating the criteria of death." ${ }^{63}$ Since that time, numerous Conservative rabbis have touched upon the subject, including Rabbi David Feldman, ${ }^{64}$ Rabbi David Golinkin, ${ }^{65}$ Rabbi Avram Reisner, ${ }^{66}$ Rabbi Elliot Dorff, ${ }^{67}$ Rabbi Joseph Prouser, ${ }^{68}$ and Rabbi Aaron Mackler. ${ }^{69}$ All of these authors accept the theory of brain-death, though only Golinkin and Reisner specify clinical tests necessary for this diagnosis to be halakhically accepted.

The Reform Movement's Central Conference of American Rabbis has published a responsum on the harvesting and storage of organs for transplantation

62 b. Sanh. $72 b$.

63 Daniel C. Goldfarb, "The Definition of Death," and Seymour Siegel, "Updating the Criteria of Death," Conservative Judaism 30, n. 2 (Winter 1976): 10-39.

64 David M. Feldman, "Rabbinic Comment: Definition of Death and Dying," The Mount Sinai Journal of Medicine 51, no. 1 (January-February 1984): 73-76.

65 Rabbi David Golinkin, "Responsum Regarding Organ Transplantation" [in Hebrew], Responsa of the Law Committee of the Rabbinical Assembly in Israel, vol. 5: 121-122.

66 Avram I. Reisner, "Care for the Terminally Ill: Halakhic Concepts and Values," in Life and Death Responsibilities in Jewish Biomedical Ethics, ed. Aaron L. Mackler (New York: Jewish Theological Seminary, 200o): 278-281, n. 5.

67 Elliot N. Dorff, "End-Stage Medical Care: Practical Applications," in Life and Death Responsibilities, 351.

68 Joseph H. Prouser, "Ḥesed or Hiyuv? The Obligation to Preserve Life and the Question of Postmortem Organ Donation," in Life and Death Responsibilities, 455-456.

69 Aaron L. Mackler, "Respecting Bodies and Saving Lives: Jewish Perspectives on Organ Donation and Transplantation," Cambridge Quarterly of Healthcare Ethics 10 (2001): $424 \mathrm{f}$. 
that approves the use of brain-death criteria accepted by the medical profession but does not stipulate its own standards. ${ }^{70}$ Rabbi Moshe Zemer reviews the relevant literature and observes that "the halakhic test for death, the cessation of breathing, parallels the modern medical test for brain-death." Although he does not endorse any specific diagnostic test, Rabbi Zemer accepts the finality of the brain-death diagnosis for organ donation and saving a life. ${ }^{71}$

A great deal has been published on this subject by Orthodox rabbis, with two distinct camps emerging. One side is led by Rabbi J. David Bleich, who has argued that unless the complete lysis (liquefaction) of the brain can be proven (which it can't without autopsy), the diagnosis of brain-death has no halakhic standing. ${ }^{72}$ Prominent Haredi poseqim have adopted this position as well. On the other side are Rabbi Moshe Tendler, Dr. Fred Rosner, ${ }^{73}$ and the Israeli Chief Rabbinate, ${ }^{74}$ who argue that brain-death is comparable to the descriptions of spinal cord destruction or decapitation made in early rabbinic sources..$^{75}$

A central drama of this debate has been determining the final opinion of Rabbi Moshe Feinstein, z"l, whose authority is accepted by all of these rabbis, but whose thoughts on brain-death evolved and remained finally subject to dispute. ${ }^{76}$

Many of these articles focus on intracranial blood flow tests, with rabbis such as Shlomo Zalman Auerbach z"l warning that injecting substances for the radionuclide test into a dying patient may hasten his death and is therefore forbidden. ${ }^{77}$ Nevertheless, these poseqim contemplate the significance of such tests done after the fact — do they prove death?

70 Central Conference of American Rabbis, Contemporary American Reform Responsa, \#78. Available online at: www.ccarnet.org.

71 Moshe Zemer, "Determining Death in Jewish Law," in Death and Euthanasia in Jewish Law: Essays and Responsa, ed. Walter Jacob and Moshe Zemer (Pittsburgh: Rodef Shalom Press, 1995), 108.

72 J. David Bleich, Time of Death in Jewish Law (New York: Berman, 1991). See also idem, "Neurological Criteria of Death and Time of Death Statutes," in Jewish Bioethics, ed. Fred Rosner and J. David Bleich (Hoboken, NJ: Ktav, 1979, 20oo), reprinted from Tradition 16, no. 4 (Summer, 1977).

73 Fred Rosner and Moshe David Tendler, "Definition of Death in Judaism," The Journal of Halacha and Contemporary Society 17 (Spring 1989): 14-31.

74 "Brain Death and Heart Transplants: The Israeli Chief Rabbinate's Directives," trans. Yoel Jakobovits, Tradition 24, no. 4 (Summer 1989): 1-14.

75 For a review of Orthodox discourse, see Avraham Steinberg, Encyclopedia ofJewish Medical Ethics (1998 Hebrew original; 2003 English Feldheim edition, trans. Fred Rosner), 2:695711.

76 See Yitzhok A. Breitowitz, "The Brain Death Controversy in Jewish Law," available online at: www.jlaw.com/Articles/brain.html.

See Abraham S. Abraham, Nishmat Avraham, vol. 2 Yoreh Deah: Medical Halacha for Doc- 
Dr. Fred Rosner uses the decapitation texts (particularly the Shulhan Arukh) to make the case that any injury which effectively severs communication between body and brain is tantamount to death, even if cardio-pulmonary signs of life persist. ${ }^{78}$ Rabbi Bleich argues strenuously against the equation of braindeath with decapitation, claiming that only the complete lysis of the brain (and perhaps not even that) could be considered tantamount to physical decapitation. ${ }^{79}$

In an extensive footnote contained within his CJLS-approved paper on end of life medical care, Rabbi Reisner cogently defends the position of Rabbi Tendler and Dr. Rosner against Rabbi Bleich's requirement of the complete destruction of the brain to declare death:

Decapitation does not signal total destruction of the tissue of the brain, but only its loss of contact with the organism. Destruction of the brain tissue will surely follow, but only at some unspecified later time. It is precisely the irreversible cessation of the integrated function of brain and body that is modeled by decapitation. ${ }^{80}$

Based on this argument of integrated function, Reisner finds the Uniform Declaration of Death Act acceptable under halakhah, provided that the appropriate diagnostic tests have been completed. Despite continued opposition by prominent Israeli poseqim such as Rabbi Yosef Shalom Elyashiv, the Israeli Chief Rabbinate has issued a similar finding, which has been the basis of successful heart transplant programs in Israeli hospitals.

\section{The Heart of the Matter}

However, Rabbi Bleich's fundamental objection to brain-death rests not on any claims regarding the integrated functioning of the brain. The cornerstone of his argument is that heartbeat is the primary criterion of life. ${ }^{81}$ In order to make

tors, Nurses, Health-Care Personnel and Patients (New York: Mesorah Publications, 2003), 310.

78 Fred Rosner, Bioethics (Hoboken, NJ: Ktav Publishing House, 2001), ch. 22, "Definition of Death," 297 .

79 Time of Death, 131-135, esp. n. 4.

$80 \quad$ "Care for the Terminally Ill," 28 o.

81 Time of Death, 148-154. 
this argument, he must set aside the clear meaning of the standard texts found in Yoma, Hullin, Gittin, Ohalot as well as the codes of Maimonides and Rabbi Karo.

Rabbi Bleich bases his argument primarily on Rashi's comments on b. Yoma $85{ }^{3}{ }^{82}$ Bleich claims that the heart itself is to be considered an איבר-one of his limbs. Although the heart is indeed counted by the Rabbis among the 248 איברים (body parts), in this context such a reading is unpersuasive. Rashi's phrase, שאינו מזיז איבריו ("he doesn't move his limbs"), clearly refers to voluntary movement. If Rashi meant to include the heart in this phrase, then the Gemara's question would be rendered non-sensical. We would have to understand it: "If the person appears dead, for he is not moving his limbs, [not even his heart], then how far should we excavate - to his heart, or to his nose-to know the truth?"

Rabbi Bleich also cites Rashi's explanation of דמר אמר, the position in the Gemara that lack of heartbeat would suffice to declare death. Rashi explains this position with the words, שנשמתו דופקת שם, "for it is there that the soul beats" [his translation]. Bleich takes this as Rashi's own position, and neglects to mention that this gloss is simply Rashi's explanation of the opinion that was rejected by all codes of Jewish law. He acknowledges that Rashi's commentary is not viewed as an halakhic code but persists in using it to build an untenable position.

Rabbi Bleich also argues against the halakhic significance of spontaneous respiration. He notes that victims of polio epidemics in the last century often suffered respiratory paralysis, and yet were conscious and able to converse with the assistance of an iron lung. By the standard of spontaneous respiration, he asserts, they would absurdly have to be considered dead. He further cites the example from b. Git. $70 \mathrm{~b}$ to prove that a man who cannot breathe is still considered alive enough to execute a writ of divorce.

Rabbi Bleich's examples are interesting, but are the cases indeed comparable? The polio victims exhibited חיות, other tangible indications of life, including the ability to talk. The Gittin case, which is frankly difficult to imagine possible, describes a man who is able via pantomime to execute a complicated document despite his slit trachea. The brain-dead individual, in contrast, is permanently unconscious, unresponsive to stimuli and unable to breathe. He or she is, to use Rashi's earlier phrase, דומה למת שאינו מזיז איבריו, "like dead, for he doesn't move his limbs." Bleich argues that the halakhah pays no heed to consciousness in the diagnosis of death. This may be true, but he himself argues

82 See above, 7 . 
that bodily movement has significance. From the case of Eli, discussed in b. Hul. 21a, we learn that the context of an observation is significant. Normally, the neck would need to be nearly severed, making respiration impossible, for the person to be declared dead without further examination. Because of Eli's advanced age, he was declared dead even without his neck being severed. Based on the Talmudic sources, we can say that a person who lies still, and appears dead, and is not breathing, as is the case with brain-death-is dead.

Even Bleich's prooftexts work against his argument for a cardiac, rather than a respiratory, standard. He cites a responsum of Hatam Sofer ${ }^{83}$ out of context which purportedly proves that cardiac activity is more important than respiration. This responsum ${ }^{84}$ is a polemic against those secular authorities and maskilim who wished to delay burial until the body began to decompose. ${ }^{85}$ Hatam Sofer vigorously asserts the adequacy of respiratory arrest in proving death.

Referring to the story of Elijah's miraculous resuscitation of a boy who had stopped breathing (1 Kgs 17:17), Rabbi Sofer mentions a condition called שיתוק or שלאג in which a pulse could be felt at the neck even though the person was apparently not breathing. Some would say therefore that Elijah merely restored breath to the boy, but Sofer sees the boy's respiratory arrest (even with continued heartbeat!) as a true death, and Elijah's act of resuscitation as a true resurrection of the dead.

In normal cases, Sofer continues (addressing the skeptical maskilim), when a body is still as a stone, and there is no heartbeat, and there is no breath, then the person is surely dead and can be buried without further delay. Bleich seizes upon this sentence as proof that Sofer requires stillness. Cardiac arrest and respiratory failure to certify death. Once again, a careful reading belies Bleich's claim. To skeptics who would require waiting until putrefaction before burial, Sofer cites every possible proof of death-rigor mortis, asystole, and apnea - to prove the finality of the diagnosis. But as far as the halakhah is concerned, respiration is the sole criterion. In a passage which Bleich does not quote, Hatam Sofer endorses the respiratory standard of death in the strongest possible terms:

כשפסקה נשמתו שוב אין מחללין שבת וע"כ כלל הוא לכל המתים שזהו שיעור המקובל

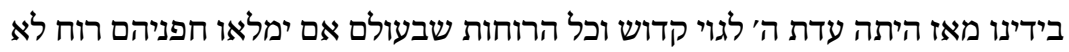
יזיזונו ממקום תורתינו הקדושה.

83 Rabbi Moses Sofer, 1762-1839.

84 שו"ת חתם סופר חלק ב (יורה דעה) סימן שלח.

85 See above, p. 7 . 
Once his breathing ceases, one should no longer violate Shabbat [to rescue him]. This is the general principle for all who die, and this has been the accepted criterion in our hands ever since God's congregation became a holy nation and should all the winds in the world fill their sails with wind they would not budge us from the place of our holy Torah!

Bleich has tried very hard, but the Hatam Sofer will not be budged from the traditional halakhic definition of death: permanent respiratory arrest. Indeed, Rabbi Shlomo Zalman Auerbach reaffirms the respiratory standard in his early responsum on the topic: ${ }^{8}$

כי נלענ"ד שאמת הדבר דכל מי שפסקה נשימתו ולא הצלחנו להחזיר נשמה באפו ומת

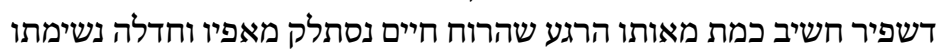

For it seems, in my humble opinion, that the truth of the matter is that anyone who has ceased breathing, and in whose nose we have not succeeded in restoring breath is dead. He should be considered to have died from the very moment when the breath of life departed his nostrils and his breathing ceased.

Yet Rabbi Bleich remains convinced of the cardiac standard. He summons nonhalakhic sources such as Rabbenu Bahya's homiletical comment about the need to love God "with all your heart," for that is the final organ to die. He also cites a responsum of Hakham $\mathrm{Tzvi}^{87}$ regarding whether a chicken whose heart could not be located should be deemed tereifah. ${ }^{88}$ Based on his understanding of anatomy and Kabbalistic beliefs, ${ }^{89}$ Hakham Tzvi proclaims the heart to be essential to all life. This may or may not be the case-mechanical hearts are no longer theoretical—but it does not displace the clear halakhic definition of death: respiratory failure.

Another prominent halakhic authority, Rabbi Ahron Soloveichik, has advanced an even more restrictive definition of death. ${ }^{90} \mathrm{He}$ argues that the

86 Rabbi Shlomo Zalman Auerbach, Minhat Shlomo 2.86.5 (1 Adar 5728/ March 1, 1968). As we shall see, he eventually rejected brain-death based on concerns about blood flow studies hastening death.

87 Rabbi Tzvi Hirsh ben Jacob Ashkenazi, 166o-1718.

88

89

90
שו"ת חכם צבי סימן עז ד"ה אצבי"ה סבור.

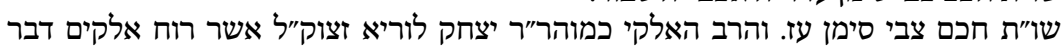

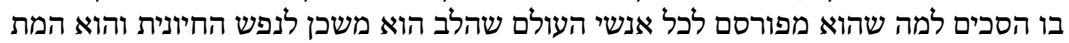

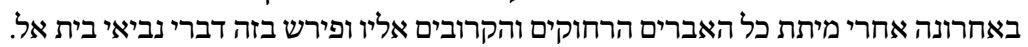
Rabbi Ahron Soloveichik, "Death According to the Halacha," The Journal of Halacha and Contemporary Society (Spring, 1989): 41-48. 
halakhah requires three criteria for the declaration of death: respiratory, cardiac and neurological.

The process of death begins with cessation of respiration and it ends with the total termination of all the three vital functions in life-respiration, cardiac activity, and brain activity ... A person who becomes devoid of respiration but who still has cardiac activity is considered semi-alive and semi-dead. Consequently, if someone will kill him, he will be considered a murderer. Hence, it is absolutely forbidden (יהרג ואל יעבור) to cut out the heart of that person even though the removal of the heart of the donor is indispensable to the preservation of the life of the donee.

This argument is powerful, but on what is it based? None of the halakhic texts present these three criteria of death - respiratory, cardiac and neurologicalas a unified set. The category of being "semi-alive" is apparently Rabbi Soloveichik's own invention. He bases the cardiac criterion upon the same philosophical, homiletical and Kabbalistic texts about the heart cited by Rabbi Bleich from Moreh Nevukhim, ${ }^{91}$ Rabbenu Bahya, and the Hakham Tzvi's citation of Rabbi Yitzhak Luria. These texts do not relate to the Talmudic criteria of death, nor are they presented as halakhic rulings. Soloveichik goes so far as to claim that brain waves registered on an EEG constitute bodily "movement" but even Bleich finds this difficult to accept. ${ }^{92}$ As we have seen, the Talmud and codes of law focus on lack of respiration, not cardiac activity — and certainly not brain activity - for the diagnosis of death.

Within the Haredi community, statements made by prominent poseqim against brain-death continue to carry great influence. Like Rabbi Feinstein, Rabbi Auerbach's position seems to have vacillated based on continued medical updates (and lobbying). His writing assumes that the blood flow test is the final determination of brain-death, but even if that test is met, he considers the patient a goses until the heart has permanently stopped. Rabbi Auerbach ultimately rejects the brain-death standard, apparently without realizing that brain-death today establishes the complete and permanent cessation of respiration. ${ }^{93}$

Nevertheless, within the Orthodox community, support for the donation of vital organs is growing, as evidenced by the advocacy organization H.o.D.s.

$91 \quad$ Section 1.39.

92 "Neurological Criteria of Death," 333.

93 See Nishmat Avraham, $313 \mathrm{f}$. 
(Halachic Organ Donor Society). ${ }^{94}$ Dr. Avraham Steinberg's recent article in The Encyclopedia of Jewish Medical Ethics reviews the primary halakhic approaches to brain-death, and concludes that permanent cessation of spontaneous respiration is the halakhically-significant criterion of death in these circumstances:

Based on the above-mentioned criteria, the establishment of the moment of death as being defined as the complete and irreversible cessation of spontaneous respiration is not a change in the halakhahh. What has changed is the medical technology to establish that the cessation of respiration is absolute and irreversible. ${ }^{95}$

Heart and liver donations are accepted by observant Jews; it is clear that they may also be donated by observant Jews so long as the appropriate criteria are met for the halakhic diagnosis of death. To accept organs donated by gentiles מילול מי מי 'ה, the desecration of God's holy name. ${ }^{96}$

\section{Conclusion}

Jewish law has consistently favored the respiratory standard for the determination of death. Although Rashi on b. Yoma 85a implies that the respiratory standard was adopted due to ease of diagnosis, the Gemara states that breath is נשמת חיים, the essence of life. The sources that we have cited from b. Hul. 21a, m. 'Ohal. 1:6 and b. Git. 7ob view severe neck injury, destruction of the spinal cord or decapitation as tantamount to death. We have concluded that these cases are distinguished by the inability of the victim to breathe. Because the protocol for ascertaining brain-death currently includes verification of the complete cessation of respiration, it suffices to prove halakhic death.

This understanding differs from that advanced by previous advocates of accepting brain-death such as Rosner, Tendler and Reisner, who view the neu-

94 See their web site, www.hods.org. They are neutral on the brain-death controversy, presenting both sides of the debate.

95 Avraham Steinberg, "Moment of Death," in The Encyclopedia of Jewish Medical Ethics, trans. Fred Rosner, 3 vols. (New York: Feldheim Publishers, 2003), 2:702. Emphasis in the original.

96 Rabbi Auerbach rules that one may accept organs from a brain-dead donor in the diaspora, where it can be assumed that the donor is non-Jewish, and that doctors will remove organs regardless of the halakha. In Israel, however, he forbids acceptance of such organs for fear of encouraging the hastening of death in a goses. 
rological injury suffered to the brain stem as halakhically significant in and of itself. Our position focuses on the inability to breathe caused by brain-death as the halakhically-significant criterion.

A diagnosis of brain-death, according to its rigorous protocol, is required for halakhic purposes only when contemplating an action such as the harvesting of vital organs. ${ }^{97}$ It may be possible one day to transplant the hearts and livers of non-heart beating donors, thereby avoiding this ambiguous situation. ${ }^{98}$ Meanwhile, the brain-death protocol with its test of apnea satisfies the traditional definition of death established in b. Yoma 85a and the codes that follow it.

We must remain clear that the stringent criteria proposed by Wijdicks and Plum et al. to rule out any temporary or reversible factors, followed by careful clinical examination, are prerequisites to the diagnosis of death according to halakhah. The brain-reflex clinical examination should indicate whether the components of the brain stem-mid-brain, cerebellum, pons and medulla oblongonta - have indeed ceased to function. These examinations are also preliminary to the halakhic diagnosis of death. They satisfy Rashi's explanation of b. Yoma $85 \mathrm{a}$, that the patient is utterly unresponsive. These tests also can prevent medical staff from performing an apnea test which could be dangerous for a patient who does retain brain function, and whose death could be hastened by a premature apnea test.

What about the continued heartbeat? It seems counterintuitive to dismiss this rhythmic function as פרכוס, which is generally spasmodic movement after death. Yet the heart is a muscle which can continue to beat even outside of the body (as it often does during heart-transplant operations). We do not consider a heart transplant recipient to have died and been reborn. Asystole alone does not define death, and continued heartbeat may indeed qualify as פרכוס.

97 If the proposed course of action is to remove futile treatments that are deemed an impediment to death, then a diagnosis of irreversible coma will suffice for a shift to palliative care. Dr. Hayim Brodie notes that the brain-death diagnosis may also be used to justify withdrawal of life support for a patient who has no relative or guardian. Conservative movement authors are divided about the withdrawal of artificial nutrition and hydration, but this controversy obtains in cases of coma, rather than brain death. See Rabbi Dorff and Rabbi Reisner, in Life and Death Responsibilities in Jewish Biomedical Ethics.

98 A notable development in the field is the "Pittsburgh Protocol" which involves terminating artificial respiration allowing the patient to go into cardiac arrest in the operating room and, after a few moments of official death, proceeding with the harvesting of vital organs. This procedure, which does not establish irreversibility, raises numerous ethical and halakhic difficulties, and is to be the subject of a separate study by Rabbi Dorff. 
Heartbeat alone does not constitute a נפש חיה, a living person, either in the womb or in the ICU. The brief persistence of cardiac activity in cases where there is no consciousness, no movement in response to any neurological examination, nor any spontaneous respiration as demonstrated by the apnea test, is consistent with a declaration of death in halakhah. The cardiac standard has clearly been rejected by the Gemara and codes in cases where the person is found to be דומה למת, "like dead."

The apnea test confirms that the brain stem has ceased to function and also meets the traditional respiratory criterion of death. This is the halakhicallysignificant and final determination of death. Indeed, a patient who fails to breathe during the apnea test, showing no signs of spontaneous respiration after all the preliminary confounding factors and brain reflex exams have been accounted for, is dead by both classical Jewish and contemporary medical criteria. The moment that this test is completed can serve as the official moment of death according to halakhah.

[2018 update: As noted above, recent medical literature has drawn attention to conditions such as upper spinal cord injury and global ischemic penumbra which could mimic brain-death on the clinical exams and apnea test. We would not go so far as Dr. Alan Shewmon in declaring brain-death to be an unusable diagnosis absent currently impossible proof of complete cessation of blood flow to all parts of the brain. Rather, we would caution halakhic authorities to question medical practitioners about the possibility of other conditions that might mimic brain-death, and to verify that there are no indications of consciousness, before accepting the brain-death diagnosis and permitting organ transplantation.]

This paper has of necessity focused on the technical aspects of medical practice and halakhic precedent. This should not obscure the fact that each incidence of such a death is tragic for the patient and for his or her family. Indeed, the declaration of death based on neurological criteria despite continued heartbeat can be particularly troubling for relatives who are not fully convinced that their loved one has died. The medical literature is likewise concerned with this problem. Clergy who are properly sensitive to both the halakhic and the pastoral challenges of this moment can be an invaluable resource for the grieving family. They may explain the spiritual significance of the "breath of life" and its connection to familiar Hebrew terms such as nefesh, neshama and ruach. It would be appropriate to tear a garment (קריעה) at the time that death is declared, to recite Psalms, to ask forgiveness from the deceased and to follow all of the other sensitive customs taught by our holy Torah. 


\section{Conclusion}

1. A ventilator-dependent patient with heartbeat but no apparent brain function may be declared dead based on the following criteria:

2. If, after the established waiting period, confirmatory tests and brain-reflex exams show there to be no brain function, [2018 update: and if there is no indication of confounding factors, including alternative injuries that might suppress responses to the clinical exam,] the patient shall be tested for apnea. Failure to breathe during this test (or any future procedure which verifies the absence of spontaneous respiration) proves that the patient is considered dead according to the traditional standard of Jewish law- the permanent cessation of respiration.

3. After the apnea test is concluded, ventilation shall be continued until the results are known, death is declared, and the family has had an opportunity to consider donation of vital organs to save another person's life. The donor's body should be treated with the utmost dignity and be prepared for Jewish burial at the earliest possible opportunity.

\section{Bibliography}

Abraham, Abraham S. Nishmat Avraham. Vol. 2, Yoreh Deah: Medical Halacha for Doctors, Nurses, Health-Care Personnel and Patients. New York: Mesorah, 2003.

Ashwal, Stephen. "Clinical Diagnosis and Confirmatory Testing of Brain Death in Children." In Brain Death. Edited by Eelco F.M. Wijdicks, ch. 5. Philadelphia: Lippincott Williams \& Wilkins, 2001.

Aviv, Rachel. "What Does It Mean to Die?" New Yorker, February 5, 2018. Online: https:// www.newyorker.com/magazine/2018/o2/o5/what-does-it-mean-to-die.

Bernat, James L. "Refinements in the Definition and Criteria for Death." In The Definition of Death: Contemporary Controversies. Edited by Stuart J. Younger, Robert M. Arnold, and Renie Schapiro. Baltimore: Johns Hopkins University Press, 1999.

Bleich, J. David. "Neurological Criteria of Death and Time of Death Statutes." In Jewish Bioethics. Edited by Fred Rosner and J. David Bleich. Hoboken, NJ: Ktav, 1979, 2000. Reprinted from Tradition 16, no. 4 (Summer, 1977).

Bleich, J. David. Time of Death in Jewish Law. New York: Berman, 1991.

Breitowitz, Yitzhok A. “The Brain Death Controversy in Jewish Law." Online: www.jlaw .com/Articles/brain.html.

Brody, Baruch A. "How Much of the Brain Must Be Dead?" In The Definition of Death: Contemporary Controversies. Edited by Stuart J. Younger, Robert M. Arnold, and Renie Schapiro. Baltimore: Johns Hopkins University Press, 1999. 
Cranford, Ronald. "Even the Dead Are Not Terminally Ill Anymore." Neurology $5^{1}$ (1998): $15^{15}-1516$.

Dorff, Elliot N. "End-Stage Medical Care: Practical Applications." In Life and Death Responsibilities in Jewish Biomedical Ethics. Edited by Aaron L. Mackler. New York: Jewish Theological Seminary, 2000.

Efron, John M. Medicine and the German Jews: A History. New Haven: Yale University Press, 2001.

Farber, Zev, ed. Halakhic Realities: Collected Essays on Brain Death. Jerusalem: Maggid Books, 2015.

Feldman, David M. "Rabbinic Comment: Definition of Death and Dying." The Mount Sinai Journal of Medicine 51, no. 1 (January-February 1984): 73-76.

Fishbane, Michael. The Kiss of God: Spiritual and Mystical Death in Judaism. Seattle: University of Washington Press, 1994.

Flowers, W. Mel, Jr., and Bharti R. Patel. "Accuracy of Clinical Evaluation in the Determination of Brain Death." Southern Medical Journal 93, no. 2 (February 2000): 203206.

Flowers, W. Mel, Jr., and Bharti R. Patel. "Persistence of Cerebral Blood Flow after Brain Death." Southern Medical Journal 93, no. 4 (April 200o): 364-370.

Fost, Norman. "The Unimportance of Death." In The Definition of Death: Contemporary Controversies. Edited by Stuart J. Younger, Robert M. Arnold, and Renie Schapiro, 161-178. Baltimore: Johns Hopkins University Press, 1999.

Goldfarb, Daniel C. "The Definition of Death." Conservative Judaism 30, n. 2 (Winter 1976): 10-22.

Greenberg, Gary. “As Good As Dead: Is There Really Such a Thing As Brain Death?" New Yorker, August 13, 2001, 36-41.

The Hastings Center Report. July-August 2001.

Israeli Chief Rabbinate. "Brain Death and Heart Transplants: The Israeli Chief Rabbinate's Directives." Translated by Yoel Jakobovits. Tradition 24, no. 4 (Summer 1989): 1-14.

Lewis, Ariane. "Reconciling the Case of Jahi McMath." Neurocritical Care, June 19, 2018. Lock, Margaret. Twice Dead: Organ Transplants and the Reinvention of Death. Berkeley: University of California Press, 2002.

Mackler, Aaron L. "Respecting Bodies and Saving Lives: Jewish Perspectives on Organ Donation and Transplantation." Cambridge Quarterly of Healthcare Ethics 10 (2001).

The Merck Manual of Medical Information. Second Home Edition. Whitehouse Station, NJ: Merck \& Co., 2003.

Morioka, Masahiro. "Reconsidering Brain Death: A Lesson from Japan's Fifteen Years of Experience.” The Hastings Center Report 31, no. 4 (July-August 2001): 41-46.

Newberg, Andrew, Abass Alavi, Salina van Rhijn, Adolfo Cotter, and Patrick Reilly. "Radiologic Diagnosis of Brain Death." JAMA 288, no. 17 (November 6, 2002). 
Nuland, Sherwin B. How We Die: Reflections on Life's Final Chapter. New York: Alfred A. Knopf, 1994.

Pernick, Martin S. "Brain Death in a Cultural Context: The Reconstruction of Death, 1967-1981." In The Definition of Death: Contemporary Controversies. Edited by Stuart J. Younger, Robert M. Arnold, and Renie Schapiro. Baltimore: Johns Hopkins University Press, 1999.

Plum, Fred. "Clinical Standards and Technological Confirmatory Tests in Diagnosing Brain Death." In The Definition of Death: Contemporary Controversies. Edited by Stuart J. Younger, Robert M. Arnold, and Renie Schapiro. Baltimore: Johns Hopkins University Press, 1999.

Prouser, Joseph H. "Ḥesed or Hiyuv? The Obligation to Preserve Life and the Question of Postmortem Organ Donation." In Life and Death Responsibilities in Jewish Biomedical Ethics. Edited by Aaron L. Mackler. New York: Jewish Theological Seminary, 2000.

Reisner, Avram I. "Care for the Terminally Ill: Halakhic Concepts and Values." In Life and Death Responsibilities in Jewish Biomedical Ethics. Edited by Aaron L. Mackler. New York: Jewish Theological Seminary, 2000.

Rosner, Fred. Bioethics. Hoboken, NJ: Ktav, 2001.

Rosner, Fred, and Moshe David Tendler. "Definition of Death in Judaism." Journal of Halacha and Contemporary Society 17 (Spring 1989): 14-31.

Shemie, Sam D., Christopher Doig, and Philip Belitsky. "Advancing toward a Modern Death: The Path from Severe Brain Injury to Neurological Determination of Death." Journal of the Canadian Medical Association 168, no. 8 (April 15, 2003): 993-995.

Shewmon, D. Alan. “Chronic 'Brain Death.” Neurology 51 (1998): 1538-1545.

Shewmon, D. Alan. "False-Positive Diagnosis of Drain Death Following the Pediatric Guidelines: Case Report and Discussion." Journal of Child Neurology 32, no. 14 (2017): 1104-1117.

Shewmon, D. Alan. "Truly Reconciling the Case of Jahi McMath." Neurocritical Care, August 15, 2018.

Siegel, Seymour. "Updating the Criteria of Death." Conservative Judaism 3o, n. 2 (Winter 1976): 10-39.

Singh, V., J.P. McCartney, and J.C. Hemphill, III. "Transcranial Doppler Ultrasonography in the Neurologic Intensive Care Unit." Neurology (India) (June 2001), Suppl. 1:81-89.

Soloveichik, Ahron. "Death According to the Halacha." Journal of Halacha and Contemporary Society (Spring, 1989): 41-48.

Steinberg, Avraham. "Moment of Death." Translated by Fred Rosner. Encyclopedia of Jewish Medical Ethics 2:695-711.

Swash, Michael, and Richard Beresford. "Brain Death: Still-Unresolved Issues Worldwide." Neurology 58 (2002): 9-10.

Toktzinski, Yechiel Michal. Gesher HaHaim. Jerusalem, 196o. 
Truog, R.D. “Is It Time to Abandon Brain Death?” The Hastings Center Report 27, no. 1 (1997): 29-37.

Wade, Derick T. "The Dis-integration of Death." The Lancet 36o (August 10, 2002):425426.

Wang, Michael Y., Pamela Wallace, and J. Peter Gruen. "Brain Death Documentation: Analysis and Issues." Neurosurgery, September 2002, 731-736.

Wijdicks, Eelco F.M., ed. Brain Death. Philadelphia: Lippincott Williams \& Wilkins, 2001.

Wijdicks, Eelco F.M. "Brain Death Worldwide: Accepted Fact But No Global Consensus in Diagnostic Criteria." Neurology 58 (January 2, 2002): 20-25.

Wijdicks, Eelco F.M. "The Diagnosis of Brain Death." The New England Journal of Medicine 344, no. 16 (April 19, 2001): 1215-1221.

Zemer, Moshe. "Determining Death in Jewish Law." In Death and Euthanasia in Jewish Law: Essays and Responsa. Edited by Walter Jacob and Moshe Zemer. Pittsburgh: Rodef Shalom, 1995. 